\title{
Contribution to the knowledge of ptyctimous mites (Acari, Oribatida) in the Palm House in Poznań
}

\author{
WOJCIECH NIEDBAŁA \\ Department of Animal Taxonomy and Ecology, Faculty of Biology, Adam Mickiewicz University, \\ Umultowska 89, 61-614 Poznań; e-mail: wojciech.niedbala@amu.edu.pl
}

(Received on 23 April 2010; Accepted on 23 November 2010)

\begin{abstract}
In soil samples from the Palm House (Palmiarnia) in Poznan city, six alien and six native mite species of the ptyctimous were found. Nearly half of them are semicosmopolitan but two of them are not native to Europe. One of the species, Phthiracarus phoxos Niedbała 2004, is endemic to Cuba. Supposedly the wellbeing of the exotic fauna depends on the presence of exotic soil and careful addition of native soil.
\end{abstract}

Keywords: Oribatida, ptyctimous mites, greenhouse, introduced species

\section{INTRODUCTION}

The moss mite fauna (Oribatida) of palm hauses is rarely reported in the literature. In Poland only one paper on this subject has appeared so far (SkubAta et al. 2001). Its authors reported that the moss mite fauna was not specific. The species composition was mainly dependent on the type of soil and plants coming from various sources in Poland and subjected to various agrotechnological procedures. The oribatid fauna was accidentally established as a result of using soil from different sources. Only eight species (about 13\% of the oribatid fauna of greenhouses) were found to be introduced with exotic plants (SkUbaŁa et al. 2001).

In 2005-2008, Anna Michalak, a student of the Adam Mickiewicz University in Poznań collected soil samples from the Poznan Palm House from which she extracted the fauna of invertebrates. Evaluation of the quantitative structure of this fauna was the basis of her master's thesis (MichalaK 2006) and her further research. Besides a large number of soil mites she also selected a number of ptyctimous mites. The analysis of species identified from these samples is the subject of this short note. 


\section{DESCRIPTION OF PAVILIONS}

Pavilion 1 - Subtropical vegetation. The dominant species are creeper plants and palms, e.g. old soft tree ferns (Dicksonia antarctica) and a few species of sago palms, including queen sago palm (Cycas rumphii).

Pavilion 2 - This pavilion presents the temperate zone vegetation, with a collection of plants typical of the Mediterranean region: a fruit-bearing citrus grove, a tall Canary Island date palm (Phoenix canariensis), a number of other tall palms, Chinese windmill palm (Trachycarpus fortunei), fig-tree (Ficus carica) and a 10-metre-high cork oak (Quercus suber).

Pavilion 5 - Tropical vegetation, including a formation of epiphytes, orchids, ferns, pineapples, and cacti. There is a collection of plants from the family Araceae (mainly representatives of the genera Monstera, Philodendron, Dieffenbachia, Aglaonema) and a tall plantain banana Musa $\times$ sapientum .

Pavilion 6 - Tropical vegetation with domination of trees, mostly representing the genus Ficus, arranged to reproduce a fragment of dense and dark tropical forest with aerial and supporting roots, black pepper (Piper nigrum), giant diospyros (Diospyros abyssinica), orange jasmine (Murraya paniculata), and sand-box tree (Hura crepitans).

Pavilion 9 - Xerophytes from the Old and New world and plants of the savannah, mainly representing the African flora. Particularly well represented are the species from the spurge family (Euphorbiaceae) and aloe family (Aloaceae), caudiciform plants, sag palms, and other palms. This pavilion hosts the oldest plant growing in the Poznan Palm House - a 400-year-old Australian cycad (Macrozamia moorei).

\section{LIST OF LOCALITIES AND SPECIES FOUND}

\section{December 2005}

Sample 002, litter under Bismarck palm (Bismarckia nobilis Hildebr. et Wendl.), pavilion 9

Acrotritia clavata -1

Sample 004, litter under Bushman's river cycad (Encephalartos trispinosus Dyer.), pavilion 1

Acrotritia clavata -1

Atropacarus (Hoplophorella) hamatus - 1

Sample 005, as above, another sample

Microtritia tropica -1

Sample 006, as above, another sample

Atropacarus (Hoplophorella) singularis - 1

Sample 014, under decayed, lying trunk of oak, pavilion 6

Euphthiracarus cribarius - 1 
Sample 015, as above, another sample

Mesotritia nuda - 10

Euphthiracarus cribarius - 2

Acrotritia ardua - 4

\section{April 2006}

Sample 002, litter under Bismarck palm (Bismarckia nobilis Hildebr. Et Wendl.), pavilion 9

Acrotritia ardua - 1

Sample 012, under decayed, standing trunk of beech, pavilion 6

Mesotritia nuda - 1

Sample 013, under decayed, lying trunk of oak, pavilion 6

Mesotritia nuda - 3

Acrotritia ardua - 1

Phthiracarus ferrugineus - 1

Sample 016, litter and epiphytes, pavilion 5

Acrotritia ardua - 2

\section{February 2008}

Sample 013c, under decayed, standing trunk of beech, pavilion 6

Mesotritia nuda - 5

Euphthiracarus cribarius -8

Sample 016c, from epiphytes, pavilion 5

Mesotritia nuda -4

Microtritia tropica -5

Phthiracarus phoxos - 10

Atropacarus (Hoplophorella) vitrinus -4

Sample 024c, litter under rough tree fern (Alsophila australis Brown), pavilion 1 Microtritia tropica -1

Sample 026c, litter under soft tree fern (Dicksonia antarctica Labill.), pavilion 2 Acrotritia ardua - 3

Phthiracarus anonymus -2

Phthiracarus longulus -8 
Euphthiracaroidea Jacot, 1924

Oribotritiidae Grandjean, 1954

Mesotritia nuda (Berlese, 1887)

Euphthiracaridae Jacot, 1930

Euphthiracarus cribarius (Berlese, 1904)

Acrotritia ardua (C. L. Koch, 1841)

Acrotritia clavata (Märkel, 1964)

Microtritia tropica Märkel, 1964

Phthiracaroidea Perty, 1841

Phthiracaridae Perty, 1841

Phthiracarus anonymus Grandjean, 1933

Phthiracarus phoxos Niedbała, 2004

Phthiracarus ferrugineus (C. L. Koch, 1841)

Phthiracarus longulus (C. L. Koch, 1841)

Steganacaridae Niedbała, 1986

Atropacarus (Hoplophorella) hamatus (Ewing, 1909)

Atropacarus (Hoplophorella) singularis (Sellnick, 1959)

Atropacarus (Hoplophorella) vitrinus (Berlese, 1913) semicosmopolitan

Holarctic

semicosmopolitan

Neotropical

pantropical

semicosmopolitan

endemic (Cuba)

Palaearctic

Holarctic

semicosmopolitan

pantropical

semicosmopolitan

\section{DISCUSSION}

In total, 12 species of ptyctimous mites were found in the Poznan Palm House. Six of them are alien: Acrotritia clavata, Microtritia tropica, Phthiracarus phoxos, Atropacarus (Hoplophorella) hamatus, A. (H.) singularis, and $A$. (H.) vitrinus. The others are native: Mesotritia nuda, Euphthiracarus cribarius, Acrotritia ardua, Phthiracarus anonymus, P. ferrugineus, and P. longulus. The soil in practically all pavilions is a mixture of native components and some components brought together with the plants from foreign countries, in_different climatic zones. It seems that the presence and wellbeing of the exotic fauna depends on the careful maintenance of the soil brought with the plants and addition of small amounts of native soil. This strategy was followed in pavilion 1 (samples 004, 005, 006, 024c), with exotic fauna brought in the soil from Florida, USA, and in pavilion 5 (samples 016, 016c) and pavilion 9 (sample 002), with exotic and semicosmopolitan fauna. Pavilion 5 presents the epiphytes from the Neotropical region and a Cuban petticoat palm (Copernicia macroglosa $\mathrm{H}$.Wendl). The palm was most probably brought from Cuba and that is why the most interesting endemic Cuban species Phthiracarus phoxos was found there (Figure). In pavilion 6, in the soil samples collected under tropical species (samples 012, 013, 013c, 014, 015), only European species were identified. This suggests that the native soil was prevalent there. In pavilion 2, with the Mediterranean plants (sample 026c), also representatives of our native fauna were found. 
According to the zoogeographic classification, the most numerous is the semicosmopolitan group, represented by five species, but two of them are not native to Europe: Atropacarus (Hoplophorella) hamatus and A. (H.) vitrinus. The other species found include: two pantropical, two Holarctic, and single Neotropical, endemic (Cuba), and Palaearctic species. An interesting problem is how long the exotic fauna will be present in the soil to which the native soil is continuously added. Further research on oribatid mites in the Palm House is needed to answer this question.

Phthiracarus phoxos Niedbała, 2004

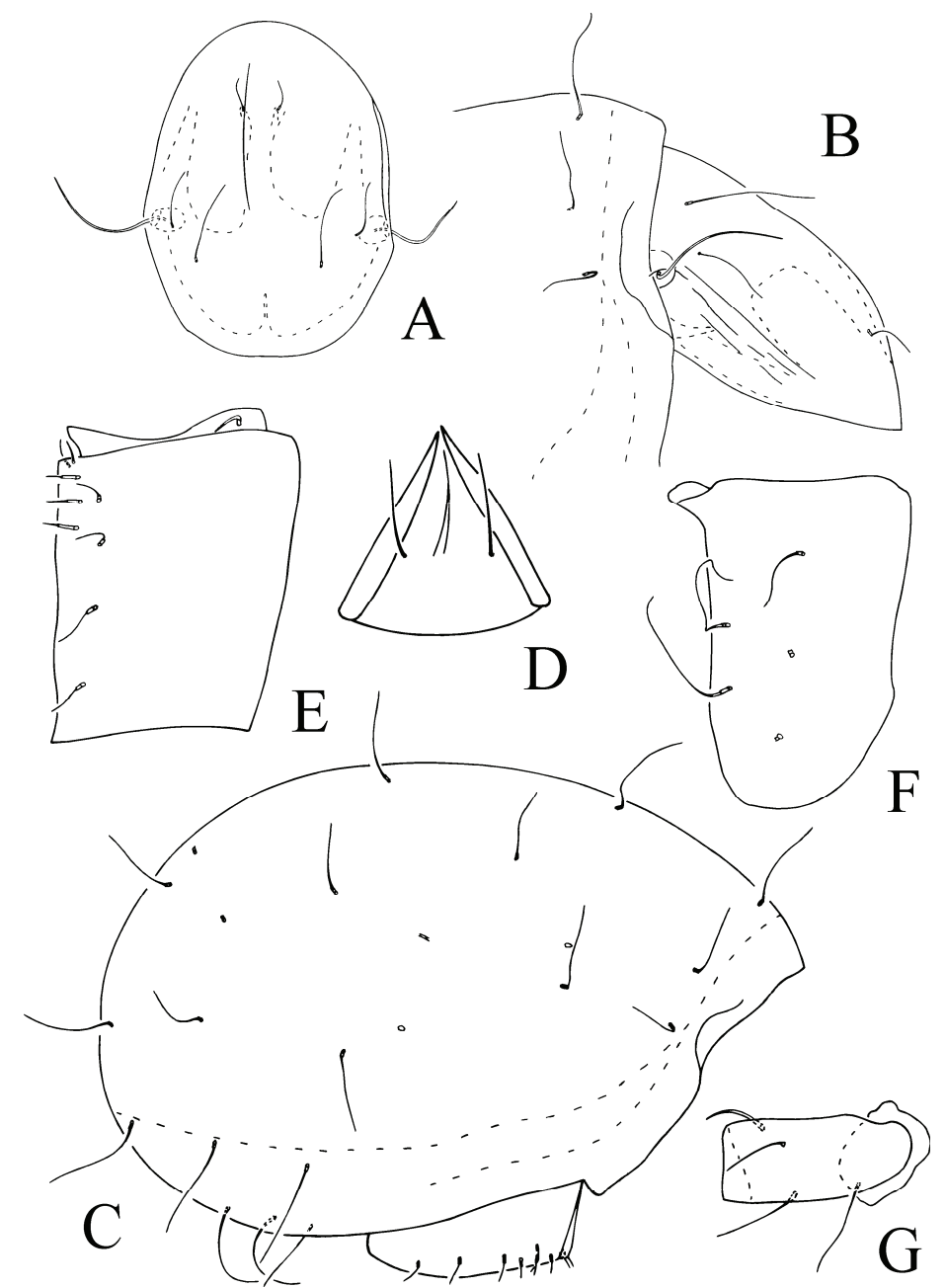

Figure. Phthiracarus phoxos Niedbała, 2004 (specimen from the Poznań Palm House): (A) prodorsum, dorsal view, (B) prodorsum and anterior part of notogaster, lateral view of the anterior part of notogaster, (C) lateral view of opisthosoma, (D) mentum of infracapitulum, (E) genitoaggenital plate, $(\mathrm{F})$ anoadanal plate, $(\mathrm{G})$ trochanter and femur I 
Prodorsum: length $242 \mu \mathrm{m}$, width $167 \mu \mathrm{m}$, height $101 \mu \mathrm{m}$; sensillus $99 \mu \mathrm{m}$; setae: interlamellar $81 \mu \mathrm{m}$, lamellar $48 \mu \mathrm{m}$, rostral $32 \mu \mathrm{m}$, exobothridial $18 \mu \mathrm{m}$. Notogaster: length $485 \mu \mathrm{m}$, width $318 \mu \mathrm{m}$, height $318 \mu \mathrm{m}$; setae: $c_{1} 81 \mu \mathrm{m}, c_{l} /\left(c_{1}-d_{l}\right)=0.7, h_{l}$ and $p_{l} 61 \mu \mathrm{m}$. Genitoaggenital plate $13 \mu \mathrm{m} \times 94 \mu \mathrm{m}$; anoadanal plate $164 \mu \mathrm{m} \times 91 \mu \mathrm{m}$.

This specimen is slightly smaller than the holotype. No significant morphological differences were noted between the specimen found in the Poznan Palm House and the holotype (NiEdBata 2004). The only differences are: the stronger marked median carina of the prodorsum; furrows under lateral carinae of the prodorsum; setae $h$ of the mentum longer than the distance between them; and the lack of setae $v$ " on femur I.

\section{REFERENCES}

Michalak A. 2006. Wpływ zróżnicowania warunków siedliskowych i szaty roślinnej w Palmiarni Poznańskiej na strukturę zgrupowań fauny glebowej [Diversity of habitats and vegetation cover in the Poznan Palm House in relation to distribution of soil fauna]. MSc thesis, Faculty of Biology, Adam Mickiewicz University, Poznań.

Niedbala W. 2004. Ptyctimous mites (Acari, Oribatida) of the Neotropical region. Ann. Zool. 54: 1-288.

Skubata P., Niemi R., Mleczko I. 2001. Oribatid mite fauna of greenhouses in Upper Silesia, Poland. Fragm. Faun. 44: 365-370. 